\title{
Factors Affecting Vasectomy Acceptability in Tanzania
}

\begin{abstract}
CONTEXT: Calls for increased inclusion of men in matters of reproductive health emphasize the need for research into vasectomy acceptability and decision making. Vasectomy is a safe, simple and effective method of contraception, but is underused worldwide.
\end{abstract}

METHODS: Focus group discussions and in-depth interviews were conducted with potential and actual sterilization clients and their partners in the Kigoma Region of Tanzania. Content analysis was used to search for emergent themes related to vasectomy decision making.

RESULTS: Six themes emerged as overarching factors contributing to the vasectomy decision-making process: economics, spousal influence, religion, provider reputation and availability, uncertainty about the future, and poor vasectomy knowledge and understanding. There was substantial communication between partners regarding the vasectomy decision, and wives had a strong influence on the outcome; however, men and women agreed that husbands would resist vasectomy if wives initially raised the topic. Vasectomy acceptance is limited by the scarcity of skilled vasectomy providers and by the fact that men and women hold many of the same misunderstandings about vasectomy, including a fear of decreased sexual performance as a result of the procedure.

CONCLUSIONS: Spousal discussions are important in the decision to get a vasectomy, but these discussions should be initiated by the male partner. Programs need to educate men about contraceptive options, including vasectomies. Detailed, culturally relevant knowledge of the barriers and facilitators individuals experience during their decisionmaking process will enable vasectomy promotion programs to more successfully target appropriate populations. International Family Planning Perspectives, 2007, 33(1):13-21

Over the past decade, calls have been made to increase the involvement of men in matters of reproductive health and family planning. Governmental and nongovernmental agencies $^{1,2}$ and international health organizations ${ }^{3-5}$ all recognize the need to include men in reproductive health services and decision making, and make convincing arguments that doing so would benefit men and women alike.

One way to foster male involvement in family planning is to give couples more contraceptive choices through the promotion of male-oriented methods such as vasectomy. Vasectomy is a safe, simple and effective method ${ }^{6,7}$ that is relatively unknown and unused throughout much of the world. Although sterilization is the most widely used contraceptive method worldwide, tubal ligation accounts for more than five times as many procedures as vasectomy. ${ }^{8}$ In 2002, vasectomy made up only $7 \%$ of all modern contraceptive use worldwide. And although vasectomy prevalence is low in most developing regions, it is especially low in Africa, where it rarely exceeds $0.1 \%$.

Moreover, the number of vasectomy users seems to have reached a plateau in recent years: The estimated number of couples using vasectomy was 33 million in $1982^{9}$ and increased to 42 million in the following decade; ${ }^{10}$ however, from the early 1990s to 2001, the number of couples using vasectomy increased by only one million, to an estimated 43 million couples. ${ }^{11}$ If we are to ask men to take their fair share of responsibility for contraception, we need to better understand how to develop effective vasectomy programs that resonate with both clients and providers.

\section{Family Planning in Tanzania}

Tanzania is the largest country in East Africa, with a population of 33.8 million. ${ }^{12}$ The Bureau of Census estimates that by 2025 , Tanzania's population will increase by approximately $60 \%$, to 52.6 million people. Although the use of any modern contraceptive method among married women has more than tripled in the past decade (increasing to $20 \%$ in 2004), unmet need for family planning remains high (22\%). ${ }^{13}$ Despite this need, long-term and permanent contraceptive methods remain underutilized: The injectable and the pill are the most widely used methods among married women, at $8 \%$ and $6 \%$, respectively. ${ }^{14}$ The use of such long-acting methods as IUDs and implants has remained low and relatively static. ${ }^{13,14}$ According to recent estimates, female sterilization is used by $3 \%$ of women who practice contraception, and male sterilization by fewer than $1 \% .{ }^{14}$ These statistics show a need for family planning services in Tanzania, and a specific need for increased knowledge of, access to and use of long-acting methods, including vasectomy.
By Arwen Bunce, Greg Guest, Hannah Searing, Veronica Frajzyngier, Peter Riwa, Joseph Kanama and Isaac Achwal

Arwen Bunce is research associate, and Greg Guest is senior research associateboth with Family Health International, Research Triangle Park, NC, USA; Hannah Searing is director of monitoring and evaluation, and Veronica Frajzyngier is monitoring and evaluation associateboth with EngenderHealth, New York; Peter Riwa is director, Healthscope, Dar es Salaam, Tanzania; Joseph Kanama is program officer, EngenderHealth, Dar es Salaam; and Isaac Achwal is medical associate, EngenderHealth, Nairobi, Kenya. 
In 2003, the U.S. Agency for International Development (USAID) chose the ACQUIRE (Access Quality, Use in Reproductive Health) project to coordinate efforts to scale up and expand facility-based reproductive health and family planning services in 18 countries across Sub-Saharan Africa, Central and South America, Asia and the Near East. In Tanzania, ACQUIRE is the central USAID-funded mechanism to coordinate family planning efforts of the Ministry of Health and other service partners. The principle content areas are family planning at the facility level (with a focus on long-acting and permanent methods), postabortion care, capacity development and reproductive health services for underserved populations, such as men. ACQUIRE provides technical assistance to the Tanzania family planning program to accomplish this mandate.

In this article, we describe the key factors that affect vasectomy acceptability in the Kigoma Region of Tanzania, an area in which ACQUIRE is focusing on the development of male reproductive health services. In Kigoma, ACQUIRE provides support of male-centered services, including vasectomy, through provision of material, technical and financial assistance to four hospitals in the region's three districts: Kigoma, Kibondo and Kasulu.

Kigoma and Kasulu Districts each have approximately 630,000 inhabitants, and Kibondo has about 415,000; ${ }^{15}$ the average household size ranges from 6.9 in Kigoma to 7.4 in Kasulu. Twenty percent of currently married women in Kigoma overall are in polygamous unions, compared with the national average of $23 \% .^{13}$ The majority of people in the region belong to the Waha ethnic group, although a substantial proportion of the population is made up of Burundian, Rwandan and Congolese refugees. Christians and Muslims make up the great majority of the population ( $40 \%$ each), whereas Animists account for about 10\%. The per capita income is US\$144, below the national average of US\$233.

Overall, the use of modern contraceptive methods in Kigoma is substantially lower than the national average ( $12 \%$ vs. $20 \%$ of currently married women). The proportions using the injectable, the pill and male condoms are all lower in Kigoma; however, the proportion relying on tubal sterilization is approximately equal to the national average. ${ }^{14}$ The annual growth rate in the region is almost double the national average ( $5 \%$ vs. $3 \%$ ), whereas maternal mortality is lower than the national average ( 340 per 100,000 births vs. 578 per 100,000 births). ${ }^{16}$

\section{METHODS}

Data

Data for the study were collected between July and August 2004 in Kigoma, Kibondo and Kasulu Districts as part of a larger ACQUIRE study designed to examine vasectomy services in Kigoma Region. Sampling was purposive; potential study participants-vasectomy clients and their wives, potential vasectomy clients and tubal ligation clients-were identified through clinic client registers.

According to the study design, vasectomy clients had to have had the procedure in the past 6-24 months to be eligible to participate; however, because few men fit that criterion, all men who had ever had a vasectomy were invited to participate. Potential vasectomy clients were men aged 33 years or older who had at least four children, had expressed a desire not to have any more children and had used (or whose wives had used) a temporary contraceptive method in the past 6-24 months. Tubal ligation clients were eligible if they had had the procedure in the past 6-24 months. To protect client confidentiality, only providers had initial access to client names and made first contact with potential study participants.

Ten in-depth interviews and three focus groups (Kigoma, n=6; Kibondo, n=10; and Kasulu, n=12) were carried out with a total of 38 vasectomy clients (Table 1 ). Three focus groups were conducted with wives of vasectomy clients (Kigoma, n=5; Kibondo, n=9; and Kasulu, n=8), three with tubal ligation clients (Kigoma, n=9; Kibondo, $\mathrm{n}=10$; and Kasulu, $\mathrm{n}=14$ ) and three with potential vasectomy clients (Kigoma, n=8; Kibondo, $\mathrm{n}=11$; and Kasulu, $\mathrm{n}=10$ ). The mean age of respondents ranged from 38 to 42 years; the average family size ranged from 5.0 to 6.6. The majority of respondents had completed primary school, although most did not continue further.

Semistructured, open-ended data collection instruments were used to ensure consistency of questions among multiple interviewers; all interviews were conducted in Swahili by native speakers. Focus group and interview guides were made up of three main question domains-participant characteristics, contraceptive decision making and perceptions of reproductive health programs. Respondents were asked the same questions in the same sequence; inductive probing on key responses was conducted. All interviews were tape-recorded, and verbatim responses to each question were translated and transcribed by local researchers, using a standardized transcription protocol. ${ }^{17}$

The study was approved by both the institutional review board of Family Health International and the National Institute of Medical Research (NIMR) of Tanzania, the country's research ethics committee. All study respondents provided written informed consent, and oral consent from each person was recorded on a cassette tape at the beginning of each interview session. Personal identi-

\begin{tabular}{|c|c|c|c|}
\hline Status & Kigoma & Kasulu & Kibondo \\
\hline Focus groups & 4 & 4 & 4 \\
\hline Vasectomy clients & 1 & 1 & 1 \\
\hline Potential vasectomy clients & 1 & 1 & 1 \\
\hline Wives of vasectomy clients & 1 & 1 & 1 \\
\hline Tubal ligation clients & 1 & 1 & 1 \\
\hline Interviews & 2 & 2 & 6 \\
\hline Vasectomy clients & 2 & 2 & 6 \\
\hline Potential vasectomy clients & 0 & 0 & 0 \\
\hline Wives of vasectomy clients & 0 & 0 & 0 \\
\hline Tubal ligation clients & 0 & 0 & 0 \\
\hline
\end{tabular}


fiers and locator information were not collected, and any identifying information inadvertently mentioned was removed from the text prior to analysis.

\section{Analysis}

We performed collaborative thematic analysis using QSR N6 software. An initial codebook, developed using a standard iterative process, ${ }^{18}$ was revised as necessary during data analysis. Results from the preliminary analysis were shared with the field team to corroborate findings and solicit input and local knowledge.

This article focuses primarily on the vasectomy decision-making process. As a result, we focused our analysis on facilitators and barriers acknowledged to be factors in an individual's or couple's decision, broader facilitators and barriers to vasectomy uptake (e.g., access to service, transportation, governmental policies), issues relating to the process of the vasectomy decision or procedure, and program recommendations from the study respondents.

For both interviews and focus groups, we conducted frequency reports and cross-tabulations to determine the relative importance of themes in the data and their linkages to one another, using the transcript or data collection event as the unit of analysis. On the basis of these calculations, we combined and reanalyzed some codes with similar characteristics. Separate analyses were conducted by sex, type of interviewee (e.g., vasectomy client or potential vasectomy client) and district. We conducted a detailed review of the focus group data to ensure that weights accorded to themes emerging from focus groups were accurate. We compared results between in-depth interviews and focus groups and, given the similarity between the guides and the fact that we found no major substantive differences between the two analyses, present the findings together.

\section{RESULTS}

Six main themes surfaced as overarching factors contributing to actual and potential vasectomy clients' and their partners' decision to have a vasectomy: economics, spousal influence, religion, provider availability and reputation, future uncertainty, and vasectomy knowledge and understanding. Each of these themes was apparent in transcripts from all of the participant categories.

\section{Economics}

Economic hardship was the most frequently mentioned reason for vasectomy acceptance. Respondents commented on the general economic benefits of a smaller family, and anticipated problems covering the basic needs of many children, including adequate food, health care and education. One participant explained:

"When we were increasing the generation, we found that we did not get any progress in life-even buying soap was a problem; [seeing] that the children we had were enough, we decided to accept the services. By this time we had five children."-Vasectomy client, Kibondo

The ability to afford to educate one's children was the most frequently mentioned economic motivation for vasectomy. Many respondents said that education is a necessity for both males and females, and that smaller families allow parents to send all of their children to school, which in turn will allow them to advance in life. One respondent explained it this way:

"For example, if you cannot educate your child if she is a female, you may cause her to be selling oranges or to become a sex worker. If he is a male and you can't give him education, expect him to be a hawker. Those are the consequences I was trying to look at, and decided that the family I had by that time of five children was enough." -Vasectomy client, Kigoma

We considered the transcripts by respondent's gender and discovered a more nuanced story. Although economic concerns were the substantive issue most frequently mentioned by male respondents, they did not figure prominently in women's discussions. Similarly, the necessity of educating one's children was primarily mentioned by men.

\section{Spousal Influence}

Both men and women indicated that wives play an important role in the vasectomy decision, with the topic being mentioned in 21 of 22 transcripts. Concern for one's wife was a commonly mentioned theme; it encompassed a desire to stop the cycle of problem pregnancies and births, to free her from family planning methods perceived to be potentially harmful and to "rescue" her from undergoing tubal ligation surgery. One man explained his concern over the effects of multiple births:

“...I was sympathetic towards my wife's health. She was already tired and her health condition was already deteriorated because of childbearing."-Vasectomy client, Kibondo

Half of vasectomy clients specifically stated that they had been dissatisfied with a former method of birth control, primarily because of the side effects experienced by their wives. These side effects included continuous and irregular bleeding, dizziness, weight gain and lack of sexual arousal. One man reported:

"Initially my partner tried to use [the] injectable. She was injected only one injection and never repeated it. This was because she started bleeding continuously and excessively. Therefore, we stopped it "til we got [a vasectomy]." -Vasectomy client, Kibondo

Also, some vasectomy clients recognized that, compared with female sterilization, vasectomy is a relatively minor procedure. One man commented:

"I heard for the first time that it was better for a man to undergo vasectomy rather than a woman undergoing tubal ligation.... This is because it happens sometimes that a woman experiences irregular heavy bleeding after tubal ligation."-Vasectomy client, Kasulu

A number of vasectomy clients noted that their wife's refusal to undergo tubal ligation-even though they had agreed as a couple to stop childbearing-forced them into having a vasectomy. 
A wife's approval was seen as key to many vasectomy decisions. All vasectomy clients reported discussing the decision with their spouse, and more than half mentioned their wife's approval as a factor in the decision; however, five men noted that their wives convinced them to postpone the vasectomy until after they had had more children. A majority of the wives of vasectomy clients stated that they had agreed to the surgery. One woman explained her reaction to the idea:

"When he decided to use vasectomy he involved me and so I gave him a go ahead. He said that it's a very long time that I have been suffering so he should go instead, and I said go!"-Wife of vasectomy client, Kibondo

Four potential vasectomy clients said that their wives disapproved of the procedure. Reasons for women's negative attitude included a desire for more children, a lack of trust in their husband's future actions and concerns about the loss of their husband's sexual ability. One man explained:

"My wife has not yet agreed to the use of vasectomy, and I can't use it before we agree together. But I hope that as I continue to convince her, she will accept the idea, because we are having already enough children while our economic situation is not good."-Potential vasectomy client, Kasulu

There were instances in which the wife's approval was not always deemed necessary. Two men stated that one appealing aspect of vasectomy was the possibility to do it on their own, if their wives disagreed with their decision; one woman reported that her husband had had a vasectomy without her approval.

Despite the perceived importance of the wife's influence, the majority of male and female respondents agreed that husbands would resist vasectomy if the wives were the ones who initially brought up the topic and that men would consider the procedure only if they were educated about it in a formal setting. When asked about discussing the option of vasectomy with her husband, one woman commented:

"But as a woman to talk to your husband, it is not easy. He will not accept. He will become very arrogant."-Tubal ligation client, Kigoma

In contrast, two women said they could discuss family planning with their husband, and one woman suggested a seminar to teach women how to bring up the subject.

Overall, respondents maintained that vasectomy acceptability and uptake will not increase if providers are not proactive about seeking men out and educating them. In addition, they suggested that women also be targeted, because women sometimes forbid their husbands to have a vasectomy.

\section{Religion}

According to respondents, attitudes toward contraception and, therefore, vasectomy vary by religious denomination. Respondents reported that in Tanzania, the Seventh Day Adventist Church is a strong advocate of contraception: For example, vasectomy services are provided at Heri Seventh Day Adventist Hospital and contraception is dis- cussed and promoted in sermons. Furthermore, the denomination organizes educational seminars and advertises the availability of family planning providers. One female Seventh Day Adventist explained:

"You can see children are naked, hungry and [have] bad shelter. Upon God's view, that is sin; it is torturing them. We are told to give birth to children we are able to care [for], with good health and education. If they are denied the right to have education, it is also killing them."-Tubal ligation client, Kasulu

Conversely, respondents said the Roman Catholic Church in Tanzania actively discourages the use of modern methods. A Roman Catholic woman explained:

"[The Roman Catholic Church] want us to use [the calendar method]. They say family planning ways are sins...they said when you use pills you will get cancer, and they say if the man got vasectomy he will suffer from cancer..."-Wife of vasectomy client, Kigoma

Most other denominations, including Islam, Anglicanism, Lutheranism and Pentecostalism, were seen as falling somewhere between the stances of the Seventh Day Adventist Church and the Roman Catholic Church.

Although the perception of religion's importance is clear, the degree to which it actually influences people's decision making is less so. Some potential vasectomy clients admitted that religion played a part in their decision not to undergo the procedure. One Muslim man stated:

"There is somewhere in God's book which says contraception is a sin because God said let us people multiply. So if you prevent, it means you are against God. So...I can't have it [vasectomy]." -Potential vasectomy client, Kigoma

In contrast, a similar number of people admitted to having a vasectomy or tubal ligation despite the disapproval of their church. One woman explained:

"We decided ourselves although we are not allowed. It is the situation at home plus the benefits obtained by those who engaged us to join the services although my husband is a catechist (Roman Catholic)."-Wife of vasectomy client, Kibondo

Although respondents acknowledged that many religions consider sterilization a sin, some nonetheless suggested using churches and mosques to promote family planning and vasectomy. They reasoned that places of worship reach a captive audience ready to listen to messages from religious authorities. Respondents recommended meeting with religious leaders who discourage use of modern contraceptives to address their concerns and to attempt to convince them of the need for contraception.

\section{Provider Availability and Reputation}

More than a quarter of vasectomy clients cited a lack of provider availability as an explanation for having postponed the procedure; others simply described the difficulty involved in obtaining the service. One man told of his situation:

"I think I was even late to get the service "til my children went up to five. Remember I said the ideas came when I had three children; that means had the service been there 
earlier, the number of children wouldn't have gone up to five!"-Vasectomy client, Kibondo

Providers were seen as often being unavailable or inaccessible, and there was confusion as to when providers would be in the area to answer questions and perform vasectomies. Respondents told stories of men having to return to the clinic or hospital multiple times to find an available provider; one man had to return because the clinic lacked the appropriate equipment. Also, according to the male respondents, men who have had a vasectomy often feel they have nobody to ask if they experience problems after the procedure. Only one potential vasectomy client, however, cited lack of provider availability as a reason for not having undergone the procedure. He recounted:

"I live far from this hospital, [Heri Mission Hospital], so it has been difficult for me to get appropriate contacts/ communication with responsible health officers....Last time I came here, [a friend] told me that those health officers who are the experts of vasectomy were already transferred to other places. Since then, I have been trying to get information about it unsuccessfully."-Potential vasectomy client, Kasulu

Increased provider availability and accessibility was a recommendation of all respondents. Many mentioned a need for providers to be permanently stationed in communities or, at the very least, have regularly scheduled days in the area when they could answer questions and provide services. Respondents suggested that all clinic locations have adequate equipment and supplies, and requested that providers be available for and proactive about follow-up.

Also, respondents pointed to a need for the vasectomy provider, as well as the hospital or clinic where the procedure is performed, to have a good reputation and credibility. Men are reluctant to undergo surgery, particularly on a sensitive body part, without this assurance. Respondents asked that provider skills be augmented to make vasectomies more effective and less painful. Stories of pregnancies after vasectomy and accounts of pain during and after the procedure decrease vasectomy uptake.

\section{Future Uncertainty}

Uncertainty about the future and about the ultimate effect the vasectomy will have on familial interactions was repeatedly mentioned as a barrier to vasectomy uptake. Respondents worried that a man might regret being permanently sterilized if all of his living children died or if his current wife died and he could not remarry because he could not father any children. A potential client expressed the fear this way:

"I think after cutting the [vas deferens], there will be no communication.... This means even if you desire to have more children, you will not be able to father again....You will probably be thinking had it been otherwise you would like to have more children, and suppose one of the children passes away...you will have all sorts of thoughts."Potential vasectomy client, Kibondo

The issue of faithfulness and trust in one's spouse was common in the transcripts. Male respondents worried that their wives might be unfaithful or leave if they wanted more children or if the husband's sexual performance suffered. Some pointed out that the physical evidence of infidelity (e.g., if the wife of a vasectomized man became pregnant) would lead to the end of the marriage. One man explained his initial hesitation:

"Another thing that I had in mind initially...was the fear that once you undergo vasectomy operation, your wife might lose faithfulness and bear a child with other men. And this is still a big problem to many men, especially those who are not yet to understand well. But I trust my wife very much; that is why I decided to undergo the vasectomy operation."-Vasectomy client, Kibondo

For women, lack of trust in their husbands' fidelity was both a reason for and a barrier against vasectomy. Some female respondents argued that vasectomy would ensure that they were not burdened with children resulting from their husbands' extramarital relations. One woman explained why she insisted on vasectomy instead of tubal ligation:

"The man can tell you, go and have tubal ligation. You go and have it done. Then your husband goes outside and gets a child; he will continue making you unhappy. But when you tell him to go and get vasectomy, and if he agrees and gets a vasectomy, you women will live in harmony."Wife of vasectomy client, Kigoma

Other women expressed fear that vasectomy would give their husbands free rein to be unfaithful without observable consequences (i.e., children with another woman). One woman described it this way:

"I thought for him to undergo vasectomy is a warrant for him to be promiscuous. He is sure that even if he goes out of wedlock with more than hundred women, he will never bring you home bastards. Even if he was not promiscuous, he will be tempted, because he knows there is no way his wife will know about it, because he will not bring home children from other women."-Tubal ligation client, Kigoma

One man noted that he wished his wife to have a tubal ligation. She refused because she feared he would take another woman, and so he decided to have a vasectomy. On the opposite side, one woman explained:

"Most men are reluctant about undergoing vasectomy, because they believe that their wives will scorn them. They will tell them 'You are a useless man, what kind of man are you. A man with no sperms! How can you help me!'...So there will be clashes within the home. A woman can start going out of wedlock or can even divorce. A husband will be frustrated, and if he decides to remarry, the new will also need to have children. Something which is impossible to him! So I think that is the main problem men are scared of...undergoing vasectomy."-Tubal ligation client, Kigoma

One perceived solution to this dilemma, mentioned mainly by women, is for both members of a couple to be sterilized. This would put husband and wife on an equal footing in terms of trust and fidelity. At least one woman in 
the study indicated that she and her husband had done this, and others implied that they had or were considering it.

\section{Vasectomy Knowledge and Understanding}

Lack of information, misunderstandings and rumors about the vasectomy process contribute to many people's reluctance to choose vasectomy. Vasectomy clients and their wives frequently recounted that prior to undergoing the procedure, they had been concerned by rumors of decreased sexual desire or performance. Some had heard that this side effect is instantaneous, others that it happens slowly over time. In some cases, these beliefs led men to postpone the procedure. Three potential vasectomy clients reported hearing accounts of the side effects of vasectomy from prior clients. Additional rumors included equating vasectomy with castration, believing it causes cancer, believing that sperm will accumulate in the body and have negative effects, and fears that vasectomy causes weight gain and physical weakness. One respondent reported that he had delayed having the procedure for three years because he feared that it would "...lead to the distortion of my marriage, because many were saying vasectomy destroys sexual desires and ability to do sex."-Vasectomy client, Kibondo

Many of the vasectomy clients reported that their concerns regarding sexual weakness were assuaged by service providers. Men who had already undergone the procedure may also have helped: A quarter of vasectomy clients had discussed the procedure with prior clients before making their decision.

Although many potential vasectomy and tubal ligation clients discussed rumors that vasectomy causes loss of virility, only a few said they believed them. The most common reason potential vasectomy clients gave for not obtaining a vasectomy was a general lack of knowledge about the procedure. When asked what was preventing him from having a vasectomy, one man replied:

"I had been expecting to be more educated about it, because I have no idea what is being done during the procedure. How do they start? I don't know. I need to get a whole picture about vasectomy before I decide to do it." -Potential vasectomy client, Kibondo

Respondents from all four respondent groups suggested that public education campaigns address the rumors that vasectomy affects sexual performance. They advocated stressing that a man who has had a vasectomy can still ejaculate, that vasectomy is not equivalent to castration and that there is no problem with impotence and no loss of sexual interest or energy. They further suggested that men who have already undergone the procedure should educate the community on the process and long-term effects, because they have first-hand experience and could debunk some of the more persistent rumors.

In addition, respondents suggested that any public education should include as many details as possible-not only on what a vasectomy is, but on schedules, procedures and what to expect during and after the procedure. They recommended promoting the long-term benefits of vasec- tomy, including the ability to provide food for the entire family and to send all children to school, to pay for services for the family, to have healthier children and to no longer have to worry about making one's wife pregnant.

A comment heard many times during the focus groups and interviews was that there is no dedicated space for men to learn about family planning issues. The respondents frequently pointed out that women are educated on these topics every time they go to a maternal and child health clinic-through posters, leaflets and lectures by counselors and health care providers; men, however, do not have an equivalent place and thus do not have the same opportunities to learn. A few respondents mentioned that men would not go to a maternal and child health clinic because they would feel out of place, and that men need a space where they will feel "relaxed." Some suggested a dedicated family planning office or center, or an "expert" posted locally so that everybody knew whom to go to with family planning (including vasectomy) questions.

Other proposals to increase vasectomy knowledge and acceptance included teaching children about family planning in school and targeting women in vasectomy promotion campaigns, because wives sometimes forbid their husbands to undergo the procedure.

\section{DISCUSSION}

Researchers have suggested that vasectomy is unacceptable to most African men and probably will long remain so; ${ }^{19}$ however, similar predictions made in the late 1980 s about female sterilization have proved unfounded. There is evidence that the low use of vasectomy is not entirely because of men's resistance to the method, but also because of the failure of many health professionals to make information and services available and accessible. Men are interested in family planning generally, ${ }^{20-24}$ and in vasectomy specifically. ${ }^{25}$ According to a 1997 study in Tanzania, $25 \%$ of men indicated they would consider vasectomy once they reached their desired number of children. ${ }^{26}$

The six overarching domains we identified that contribute to the vasectomy decision-making process are consistent with previous research in Sub-Saharan Africa. For example, past studies have noted the barriers posed by lack of knowledge and incorrect or incomplete information concerning the vasectomy procedure. ${ }^{27} \mathrm{~A}$ fear of impotence and the equation of vasectomy with castration have been reported in multiple studies. ${ }^{26-31}$ Past research has also addressed such barriers as wives' concerns about the sexual functioning and physical strength of their husband after the procedure, ${ }^{32}$ and the lack of access to vasectomy provision sites. ${ }^{33}$ Programs in Tanzania and Kenya have acknowledged the importance of economic pressures-particularly education-on vasectomy uptake. ${ }^{26,34}$

In our study, concern for one's spouse was a common factor in the decision to have a vasectomy, and respondents reported a considerable amount of communication between spouses during the decision-making process. The influence of the wife on the vasectomy decision appears to 
be both direct (e.g., she either agreed or disagreed with her husband's desire to have a vasectomy or refused to have a tubal ligation) and indirect (e.g., men had a vasectomy to free their wives from perceived health problems or other burdens). It is impossible, however, to tell from the respondents' comments what degree of give-and-take actually occurred during discussions between spouses.

Previous literature presents the decision to have a vasectomy as either a joint decision among couples or an autonomous choice among men. ${ }^{11}$ Landry and Ward found that although most couples agreed that the decision should be a joint one, it was primarily made by men alone. ${ }^{23}$ In our sample, some men considered or had the surgery without their partner's approval. The acknowledgment by respondents of both sexes that partners can be a strong negative force in the vasectomy decision points to the need to include women in vasectomy education.

Both men and women believed that men would not consider sterilization if the subject were introduced by their wives. This may indicate that men must learn about and consider the possibility of vasectomy on their own before bringing their partners into the discussion. If this is the case, it has important implications for successful vasectomy promotion.

Another interesting finding is that economic considerations, including the need to pay for children's education, figure much more prominently in the male transcripts. Perhaps this indicates the enduring strength of cultural expectations of men as providers. In Tanzania, economic forces have made it more difficult to feed and care for large families, and have raised the perceived benefit of education. This knowledge could guide the formation of vasectomy messages targeted to men.

Both husbands and wives expressed unease about the potential effect of vasectomy on the sexual faithfulness of their partners. This unease was linked mainly to possible dissolution of the relationship; fear of an increased risk of STI or HIV transmission was rarely mentioned. Given the relatively high rates of HIV in the country, as well as the promotion of dual methods through the Tanzania national family planning program, this omission is troubling. A more indepth understanding of local constructs of sexuality, sexual behavior and relationships, knowledge and understanding of STI and HIV transmission, and perception of risk would begin to shed light on this issue. Also, additional information is needed on the role extramarital sex plays in the contraceptive decision-making process. Further research in these areas would allow vasectomy uptake campaigns to more effectively address issues of infidelity and trust within the context of the HIV/AIDS epidemic.

It is difficult to ascertain the importance of religion in an individual's decision-making process. All respondents acknowledged that both positive and negative religious opinions exist; some said that these played a part in their decision and a few admitted to having a vasectomy despite the disapproval of their church. A more in-depth exploration into the circumstances in which some individuals choose to use family planning, including permanent methods, in opposition to the teachings of their church, would also contribute to our understanding of the role of religion in contraceptive use.

Our findings have raised further research questions. For example, what helped vasectomy acceptors decide to undergo the procedure despite rumors that vasectomy causes impotence? Though some mentioned that their fears were assuaged after speaking with a health care provider, it would be interesting to know if there were other contributing factors. Similarly, it would be useful to explore power dynamics within relationships on a larger scale, and how such dynamics affect contraceptive decision making.

\section{Study Limitations}

The need to translate respondents' comments affects the degree to which transcripts can be considered an accurate representation of what was actually said. To help mitigate this problem, transcripts were reviewed for accuracy by the on-site principal investigator, and revised when necessary. In addition, emphasis in analysis was placed on overarching ideas rather than specific word choices or phrasing.

Interview and focus group data may be subject to bias, because they are based on self-report and respondents were asked to discuss events and decisions that had occurred in the past. Finally, the small sample size and the qualitative nature of data do not allow us to generalize our findings. Nevertheless, the use of qualitative methods enabled us to gain insight into attitudes, beliefs and contextual factors that would not have been captured using survey methods.

\section{Implications}

Increased inclusion of men in family planning services and education programs is an important part of efforts to increase vasectomy uptake. Establishing separate spaces for men to learn about family planning would be an effective way of achieving this goal; these spaces could be created within outpatient departments or through community outreach activities at public gatherings. Alternatively, existing clinics should consider offering broader men's reproductive health services to enhance the appeal of family planning to men. Service delivery staff need to be better trained to address men's reproductive health needs. And because some men indicated that they would prefer to receive service and information from other men, an effort could be made to hire male staff and outreach workers.

To ensure consistent levels of vasectomy service provision, vasectomy outreach services should be regularly scheduled (e.g., on a weekly basis), and linked with community outreach and mobilization. Each facility should always be stocked with the necessary equipment and supplies, so that services can be performed whenever the provider is on-site.

Compliance with postoperation instructions must be ensured to minimize postsurgery pregnancies and thus decrease fears that the surgery could lead to infidelity. Providers should emphasize the need to use another 
family planning method for three months after the operation, and should provide clear postoperative care instructions. To decrease misunderstanding between partners, pre- and postvasectomy counseling should be conducted with the husband and wife together. Clients should be encouraged to return to the clinic for semen analysis after three months. The issue of spousal trust as a barrier to permanent contraception could also be addressed via carefully planned communications and community activities.

To increase vasectomy uptake, mass media campaigns using physicians and satisfied clients should be created to address myths and misinformation. Messages should address the key concern among both men and women: that the procedure could negatively affect men's sexual desire and performance. Highlighting the economic benefits of smaller family size may also make vasectomy more attractive to men. For example, messages could emphasize a sterilized man's ability to be a good provider for his family and his satisfaction from being able to send all his children to school.

Given a spouse's potential role in the decision-making process, promotional efforts should be directed toward women as well as men. A media campaign might convey the notion of a "satisfied spouse," who no longer has to be concerned about problematic childbirths, is sexually satisfied and has a family that is financially secure and well provided for. Such messages may resonate among women, as well as among men who are concerned about their spouse's health. Also, women could receive education regarding vasectomy in maternal and child health clinics. Counseling and promotional efforts should be directed at the couple as a decision-making unit.

\section{REFERENCES}

1. Interagency Gender Working Group/U.S. Agency for International Development (USAID), Reaching Men to Improve Reproductive Health for All: Implementation Guide, Baltimore, MD, USA: John Hopkins Bloomberg School of Public Health/Center for Communication Programs, 2003.

2. Family Health International, Involving men, Network, 2004, Vol. 23 No. 3, pp. 29-30.

3. Pan American Health Organization, Involving men in sexual and reproductive health, <http://www.paho.org/English/DPM/GPP/GH/ Men\&SRH.pdf>, accessed Oct. 15, 2005.

4. United Nations Population Fund (UNFPA), It Takes 2: Partnering with Men in Sexual and Reproductive Health, New York: UNFPA, 2003.

5. World Health Organization (WHO), Programming for Male Involvement in Reproductive Health, Geneva: WHO, 2002.

6. Wright AK, Best K and Sokal D, Recent developments in vasectomy, BMJ, 2005, 330(7486):296-299.

7. Pollack A, Carignan C and Jacobstein R, Female and male sterilization, in: Hatcher R et al., eds., Contraceptive Technology, 18th ed., New York: Ardent Media, 2004, pp. 531-573.

8. Population Reference Bureau (PRB), Family Planning Worldwide: 2002 Data Sheet, Washington, DC: PRB, 2002.

9. Liskin L, Pile J and Quillan W, Vasectomy safe and simple, Population Reports, 1983, Series D, No. 4.

10. Liskin L, Benoit E and Blackburn R, Vasectomy: new opportunities, Population Reports, 1992, Series D, No. 5.
11. EngenderHealth, Contraceptive Sterilization: Global Issues and Trends, New York: EngenderHealth, 2002.

12. U.S. Census Bureau, International database, <http://blue.census. gov/cgi-bin/ipc/idbrank.pl>, accessed Apr. 19, 2003.

13. Demographic and Health Surveys, DHS Stat Compiler, <http:// www.measuredhs.com>, accessed Sept. 8, 2006.

14. Tanzania National Bureau of Statistics and ORC Macro, Tanzania Demographic and Health Survey, Tanzania 2004 Final Report, $<$ http://www.measuredhs.com/pubs/pub_details.cfm?ID= 566\&ctry_id=39\&SrchTp=type\#dfiles>, accessed Sept. 8, 2006.

15. Tanzania National Bureau of Statistics, Population and Housing Census: 2002, <http://www.tanzania.go.tz/census>, accessed Feb. 27, 2005

16. Mbaruku $G$ et al., Estimates of maternal mortality in western Tanzania by sisterhood method, African Journal of Reproductive Health, 2003, 7(3):84-91.

17. McLellan E, MacQueen KM and Niedig J, Beyond the qualitative interview: data preparation and transcription, Field Methods, 2003, 15(1):63-84.

18. MacQueen KM et al., Codebook development for team-based qualitative analysis, Cultural Anthropology Methods Journal, 1998, 10(12): 31-36.

19. Caldwell J and Caldwell P, Africa: the new family planning frontier, Studies in Family Planning, 2002, 33(1):76-86.

20. Ezeh A, Seroussi M and Ragger H, Men's fertility, contraceptive use and reproductive preferences, DHS Comparative Studies, Calverton, MD, USA: Macro International, 1996, No. 18.

21. Grady W et al., Men's perceptions of their roles and responsibilities regarding sex, contraception and childbearing, Family Planning Perspectives, 1996, 28(5):221-226.

22. Green C, Cohen S and Ghouayel H, Male involvement in reproductive health, including family planning and sexual health, UNFPA Technical Report, New York: UNFPA, 1995, No. 28.

23. Landry E and Ward V, Perspectives from couples on the vasectomy decision: a six-country study, in: Ravindran TKS, Berer M and Cottingham J, eds., Beyond Acceptability: Users' Perspectives on Contraception, London: Reproductive Health Matters, 1997, No. 99, pp. 58-67.

24. Salem R, Men's surveys: new findings, Population Reports, 2004, Series M, No. 18.

25. Atkins B and Jezowski T, Report on the first international conference on vasectomy, Studies in Family Planning, 1983, 14(3):89-95.

26. Muhondwa E, Rutenberg N and Lusiola G, Effects of the Vasectomy Promotion Project on Knowledge, Attitudes and Behavior in Dar es Salaam, Tanzania, Nairobi, Kenya: Population Council, 1997.

27. The ACQUIRE Project, Get a Permanent Smile: Increasing Awareness of, Access to, and Utilization of Vasectomy Services in Ghana, New York: ACQUIRE Project/EngenderHealth, 2006.

28. Association for Voluntary Surgical Contraception (AVSC), Men as Partners in Ghana: Cape Coast Workshop Report, New York: AVSC International, 1998.

29. Fapohunda B and Rutenberg N, Expanding Men's Participation in Reproductive Health in Kenya, Nairobi, Kenya: African Policy Research Center, 1999.

30. Qureshi Z and Solomon M, KAP of men in Machakos Town toward vasectomy, Journal of Obstetrics and Gynaecology of Eastern and Central Africa, 1995, 11(1):10-13.

31. Binyange M et al., Vasectomy Decision-Making Rwanda, New York: AVSC, 1993.

32. Ruminjo J, Barriers to vasectomy use in Kenya, East African Medical Journal, 1999, 76(3):121-123.

33. Ross J, Mauldin W and Miller VC, Family Planning and Population: A Compendium of International Statistics, New York: Population Council, 1993. 
34. Wilkinson D et al., Improving vasectomy services in Kenya: lessons learned from a mystery client study, Reproductive Health Matters, 1996, No. 4, pp. 115-121.

\section{RESUMEN}

Contexto: Las recomendaciones y llamados para incrementar la inclusión del hombre en las cuestiones de salud reproductiva destacan la necesidad de estudiar el nivel de aceptación de la vasectomía y el proceso de la toma de decisión al respecto. La vasectomía es un método anticonceptivo seguro, simple y efectivo, pero se usa muy poco en todo el mundo.

Métodos: Se llevaron a cabo reuniones de grupos focales y entrevistas a profundidad con clientes actuales y potenciales del método de esterilización y con sus parejas en la región de Kigoma, Tanzanía. Las técnicas de análisis del contenido fueron utilizadas para identificar nuevos temas relacionados con la toma de decisión con respecto a la vasectomía.

Resultados: Surgieron seis temas como factores fundamentales que contribuyen a la decisión de someterse a la vasectomía: el costo del procedimiento, la influencia de la esposa, la religión, la reputación y disponibilidad del proveedor, la incertidumbre frente al futuro y los limitados conocimientos sobre el procedimiento. Hubo buena comunicación entre las parejas con respecto a la decisión sobre la vasectomía, y las esposas tenían una gran influencia en la decisión final; sin embargo, los hombres y las mujeres estuvieron de acuerdo en que el hombre se resistiría al procedimiento si las mujeres fueran las que plantearan inicialmente la cuestión. La aceptación de la vasectomía es limitada debido a la escasez de proveedores entrenados y por el hecho de que hombres y mujeres comparten los mismos conceptos erróneos acerca de la vasectomía, incluido el temor a que puede disminuir la capacidad y actividad sexual del hombre debido al procedimiento.

Conclusiones: El intercambio de opiniones es muy importante para la toma de decisión con respecto a la vasectomía, pero estas discusiones deben ser planteadas inicialmente por el hombre. Los programas deben educar al hombre acerca de sus opciones anticonceptivas, incluida la vasectomía. El conocimiento detallado y culturalmente pertinente sobre los factores que estimulan o disuaden la aceptación de la vasectomía les permitirá a los programas que fomentan el procedimiento dirigirse con más éxito a los grupos apropiados.

\section{RÉSUMÉ}

Contexte: Les appels en faveur d'une implication accrue des hommes dans les questions de santé reproductive soulignent la nécessité d'une recherche sur l'acceptabilité de la vasectomie et la décision qui la concerne. La vasectomie est une méthode de contraception sûre, simple et efficace, pourtant sous-utilisée dans le monde.

Méthodes: Des groupes de discussion dirigée et des entretiens en profondeur ont été organisés avec des clients potentiels et effectifs à la stérilisation et avec leurs partenaires dans la région tanzanienne de Kigoma. Les thèmes émergents relatifs à la décision de vasectomie ont été identifiés par analyse de contenu. Résultats: Six grands thèmes se sont dégagés en tant que facteurs fondamentaux de la décision de vasectomie: considérations économiques, influence de l'épouse, religion, réputation et disponibilité du prestataire, incertitude d'avenir, et faible connaissance et compréhension de la vasectomie. La décision de vasectomie s'est révélée faire l'objet d'une communication substantielle entre les partenaires, et les femmes se sont avérées exercer une forte influence sur l'issue. Les hommes comme les femmes ont toutefois convenu que les maris résisteraient à la procédure si la question était initialement soulevée par l'épouse. L'acceptation de la vasectomie est limitée par la rareté de prestataires qualifiés et par le fait qu'hommes et femmes partagent la même incompréhension de la procédure (y compris la crainte d'une performance sexuelle amoindrie).

Conclusions: Les discussions entre époux jouent un rôle important dans la décision de vasectomie, mais elles doivent être entamées par le partenaire masculin. Les programmes doivent informer les hommes sur leurs options contraceptives, y compris la vasectomie. Une connaissance détaillée et culturellement pertinente des obstacles et des incitations rencontrées lors du processus de décision permettra aux programmes de promotion de la vasectomie de mieux cibler les populations appropriées.

\section{Acknowledgments}

The authors thank the U.S. Agency for International Development (USAID)/Tanzania, for funding study implementation. They thank the Ministry of Health, Directorate of Hospital Services and Directorate of Preventive Services/Reproductive and Child Health Services, for their support of the study. The authors also thank ACQUIRE Project staff in New York and Tanzania, and Family Health International staff in North Carolina, who reviewed study instruments and article drafts. And special thanks go to representatives from the Kigoma, Kasulu, and Kibondo districts.

Author contact: gguest@fhi.org 